\title{
Establishment of a Leukemic Cell Line MT-ALL With Multilineage Differentiation Potential *
}

\author{
F. Griesinger ${ }^{1}$, J.M. Greenberg ${ }^{2}$, D.C. Arthur ${ }^{2}$, A.C. Ochoa ${ }^{1}$, C. Hurvitz ${ }^{3}$, \\ R. Brunning ${ }^{1}$, and J.H. Kersey ${ }^{2}$
}

\section{A. Introduction}

Multiple steps are involved in hematopoietic differentiation and maturation from multipotent progenitor cells to terminally differentiated cells of each lineage. The availability of recombinant growth factors and of various clonogenic precursor cell assays has provided useful information about hematopoietic precursors, notably of the myeloid lineage $[1-3]$. However, the direct evaluation of primitive human lymphohematopoietic progenitor cells has been hampered by their low frequency in normal donors and the difficulties involved in expanding them in in vitro culture $[4,5]$. Therefore, little is known about the events and mechanisms that result in the irreversible commitment of multipotent uncommitted progenitors to a specific cell lineage. Leukemias have been traditionally used as a model for lymphohematopoietic development and have been studied extensively for the expression of differentia-

1 Departments of Laboratory Medicine and Pathology, and ${ }^{2}$ Pediatrics, University of Minnesota, Minneapolis, MN 55455, USA

${ }^{3}$ Department of Pediatrics, Cedars-Sinai Medical Center, Los Angeles, CA 90048, USA

* Supported in part by the following grants for the National Institutes of Health: CA 25097 and CA 21737 and the University of Minnesota Children's Cancer Research Fund. Frank Griesinger is recipient of a fellowship from the Deutsche Forschungsgemeinschaft (Gr 301/1-1). James M. Greenberg is a Special Fellow of The Leukemia Society of America.

This work is published in the Journal of Experimental Medicine from which permission for the reproduction of figures and tables was obtained. tion antigens $[6,7]$ and recently for rearrangements of genes of the immunoglobulin supergene family [8, 9]. They are considered to represent clonal expansions of lymphoid and myeloid progenitor cells and therefore provide an opportunity to study homogeneous populations of lymphohematopoietic progenitor cells. However, leukemic cell lines with the potential for multilineage differentiation that would allow the study of early events of lymphohematopoietic development are very rare $[10,11]$. We report a novel acute lymphoblastic leukemia (ALL), MT-ALL, with a predominantly mature $\mathrm{CD} 3^{+}$TCR $\alpha / \beta^{+}$phenotype, which in response to various growth factors displays the potential for multilineage differentiation in vitro. This leukemia may be instrumental in elucidating mechanisms involved in early lymphohematopoietic development.

\section{B. Materials and Methods}

Leukemic cell cultures were set up as shown in Fig. 1 and as previously reported [12]. Southern analysis was performed according to standard methods $[12,13]$. The genomic probe $\mathrm{p} \delta 7$ detects the constant region of the T-cell receptor (TCR) $\delta$ gene (J.M. Greenberg, C.W. Wilkowski, J.H. Kersey, unpublished results). pT $\gamma 1$ is a cDNA probe derived from the leukemic cell line HPB-mlt [14], kindly provided by $\mathrm{R}$. Holcombe. The $\mathrm{T} \beta$ probe is a cDNA probe kindly provided by T.W. Mak. Methods for the lymphokine-activated (LAK) and natural killer (NK) cell assays as well as the oxygen production assay have been described elsewhere [15, 16]. 
Clinical Course of the Patient. The 15year-old caucasian male presented with hemorrhagic diathesis, hepatosplenomegaly, and mediastinal mass. White blood cell count was $759000 / \mu \mathrm{l}$, containing $99 \%$ lymphoblasts, which were $\mathrm{CD}^{+}{ }^{+} \mathrm{TdT}^{+} \mathrm{CD}^{-} \mathrm{CD}^{-}$. Complete remission was achieved lasting for 5 months. The patient relapsed and attained unsustained remissions during which peripheral blood was obtained at three different times after informed consent. The patient died 1 year after diagnosis.

\section{Results and Discussion}

The leukemia presented in the patient with a predominantly mature T-lymphocyte phenotype $\left(\mathrm{CD} 2^{+} \mathrm{CD}^{+} \mathrm{CD}^{-}\right.$ $\left.\mathrm{CD}^{+} \mathrm{CD}^{+} \mathrm{CD}^{-} \mathrm{TCR} \alpha / \beta^{+}\right)$and a morphology typical for lymphoblasts (Fig. 2A). In the presence of different recombinant growth factors, various leukemic cell lines belonging to different cell lineages were established (Fig. 1). In the presence of interleukin 3 (IL-3) and/ or granulocyte-macrophage colony-stimulating factor (GM-CSF), myeloid and monocytoid cells grew out, including terminally differentiated neutrophilic granulocytes (Fig. 2 B). The cells were myeloperoxidase positive and expressed the myelomonocytic differentiation antigens CD13, CD14, MY8, and CD33 [17], while they were devoid of T-lineage associated antigens. The oxygen radical production, which is a typical feature of mature functional granulocytes, was assessed by measuring the reduction of the reporter substrate nitroblue tetrazolium (NBT) in the presence of various stimuli [16]. After stimulation with phorbol myristate $(5 \mathrm{ng} / \mathrm{ml})$, but not with the chemotactic oligopeptide F-met-leu-phe [16], NBT was reduced, proving that the myeloid cells were at least partially functional (data not shown).

A growth factor independent (GFI) leukemic cell line was established from the IL-3 cultures. Morphologically, these were undifferentiated blasts (Fig. 2C), coexpressing T-lymphoid (CD2, CD3, $\mathrm{CD} 5, \mathrm{CD} 7, \mathrm{TCR} \alpha / \beta)$ and myeloid lineage (CD13, CD14, CD33) associated differentiation antigens. In functional studies (oxygen radical production and NK and LAK activity; Fig. 3) these cells were inactive.

In the presence of IL-2, a cell line consisting of large lymphocytes with azurophilic granules (Fig. 2D) was established. In addition to the T-lineage associated antigens, the IL-2 dependent leukemic cells expressed CD8 and Leu19, which can be found on cytotoxic Tlymphocytes $[18,19]$. Functional studies confirmed that they represented the counterpart of MHC unrestricted cytotoxic T-lymphocytes [19]. The IL-2 de-

Fig. 1. Fresh peripheral blood leukemic blasts were cultured in the presence of rh GMCSF $(10-50 \mathrm{U} / \mathrm{ml})$, IL-3 (10 U/ml), IL-2 $(100 \mathrm{U} / \mathrm{ml})$, or no growth factor. $T+/-$ : positive/ negative staining for T-lineage associated antigens; $M+/-$ : positive/negative staining for myeloid

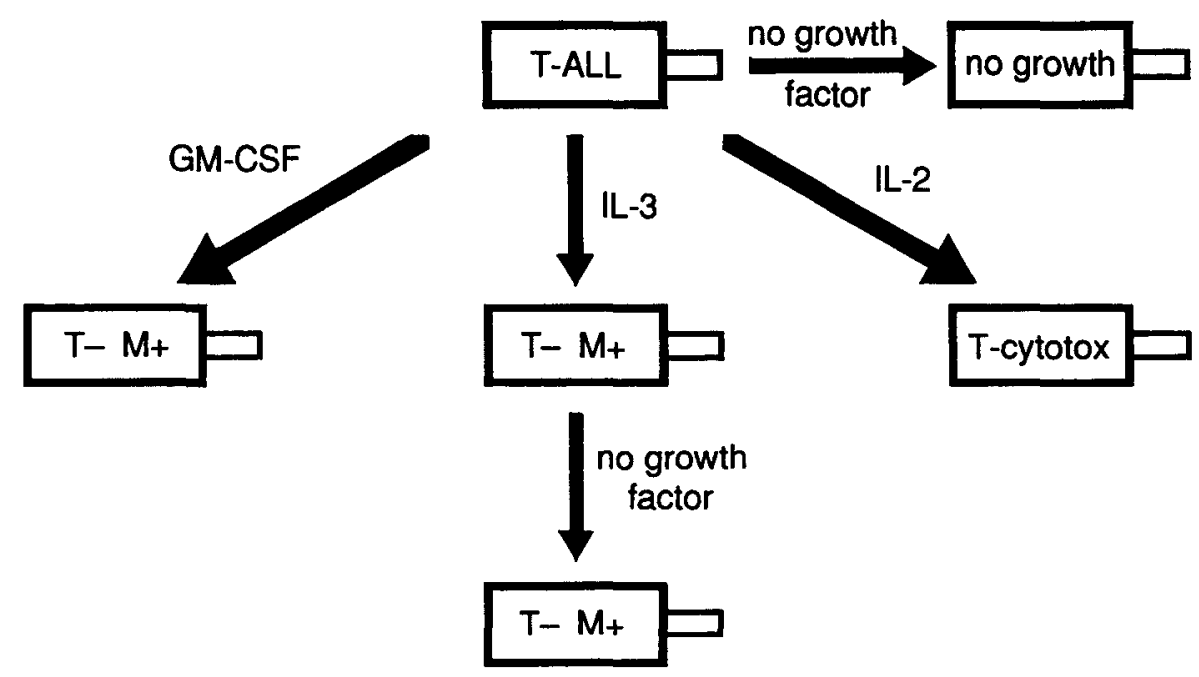
lineage associated antigens and cytochemistry; T-cytotox.: expression of a phenotype consistent with cytotoxic T-lymphocytes (see text for details) 

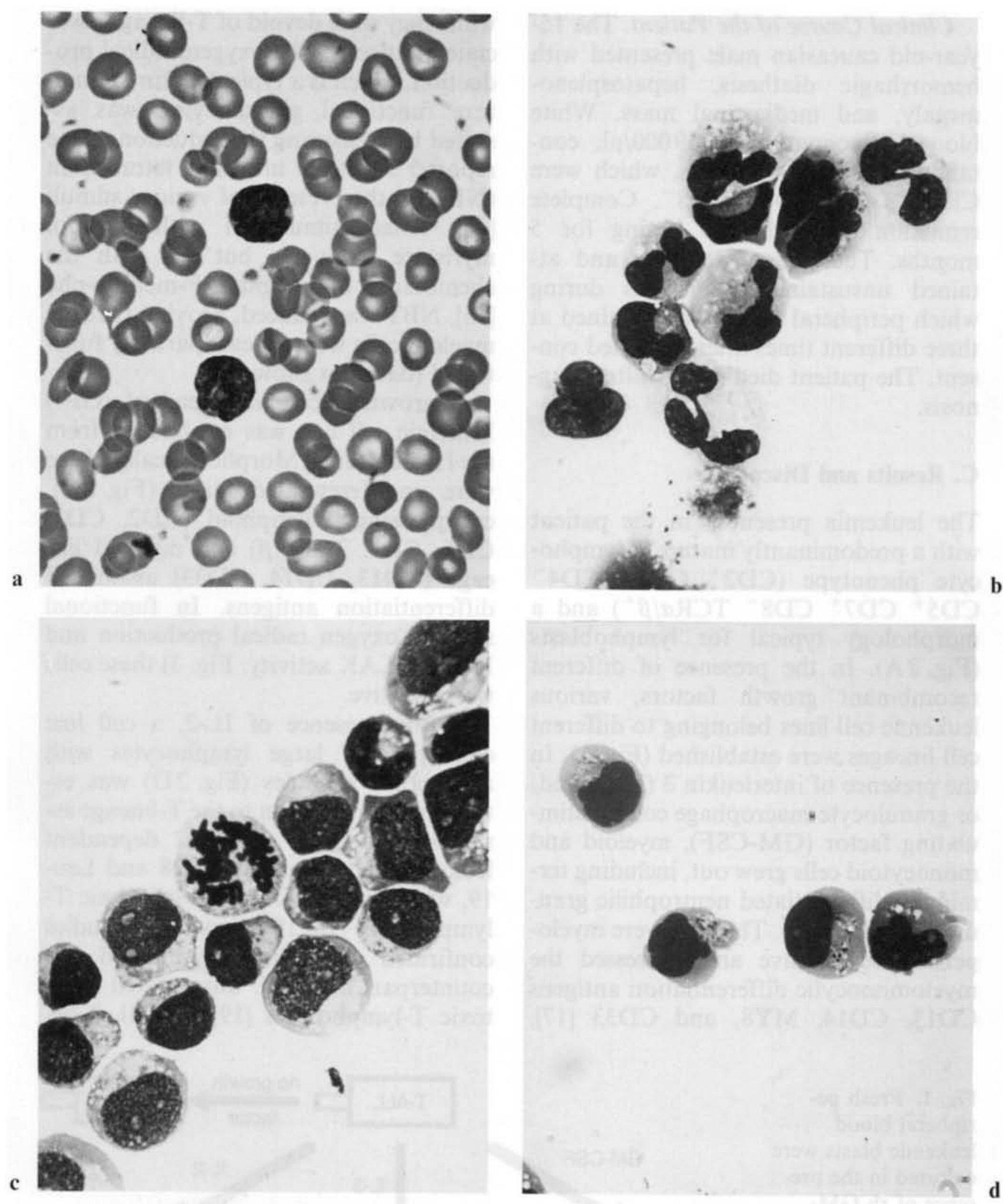

Fig. 2. a) Lymphoblasts with convoluted nuclear outlines in blood smear made from specimen from which the leukemic cell cultures were established. b) Maturing neutrophils with nuclear hypolobulation from the IL-3 cultured specimen. c) Leukemic cells with fine nuclear chromatin and prominent nucleoli from the growth factor independent leukemic cell cultures (see text and Fig. 1). d) IL-2 dependent leukemic cell cultures. The majority of these cells have distinct nucleoli and azurophilic granulation. (a-d, Wright's Giemsa, × 1200) 
pendent leukemic cell cultures exerted high lytic activity against the NK sensitive target cell line K562 and the NK resistant cell line HL-60 [15] (Fig. 3). Surprisingly, the IL-2 dependent cell line coexpressed CD33 (data not shown).

Molecular genetic analysis demonstrated unambiguously that the various leukemic cell cultures were derived from the same malignant clone. Identical, unique rearrangements of the TCR $\delta$ (Fig. 4A, B), $\gamma$ (Fig. 4C), and $\beta$ (Fig. 4D) genes were demonstrated by Southern analysis. The TCR $\delta$ gene rearrangement, detected with the TCR $\delta$ constant region probe $\mathrm{p} \delta 7$, most likely represents a V $\delta 3-J \delta 1$ rearrangement $[12,13,19,20]$. Southern analysis using various restriction enzymes and a $J \delta 1$ probe were consistent with this interpretation (data not shown). Cytogenetic analysis (Table 1) revealed a three way translocation $(1 ; 10 ; 12)$ (q25;p13;p13) and a deletion of $(6 q 15 ; q 25)$ in all cell cultures analyzed, consistent with the molecular genetic findings.

In conclusion, we have characterized a novel leukemia which gives rise to cells belonging to different cell lineages, notably T-lymphoid and myeloid. We concluded that the cell lines were presumably derived from a putative multipotent leukemic progenitor. However, the exact pathway of multilineage differentiation remains to be elucidated. One possibility is that a minor population of multipotent leukemic progenitor cells which was present in the peripheral blood blasts of the patient, but undetectable by fluorescence-activated cell sorter (FACS) analysis, differentiated in response to various growth factors into the respective lineages. Alternatively, minor populations of lineage committed cells might have acquired a growth advantage under the different culture conditions which resulted in outgrowth of the different cell cultures. A third hypothesis suggests that due to posttransformational alterations of the genetic program, the mature $\mathrm{CD}^{+}{ }^{+} \mathrm{TCR} \alpha / \beta^{+}$T-lymphoblasts were capable of undergoing lineage switch.

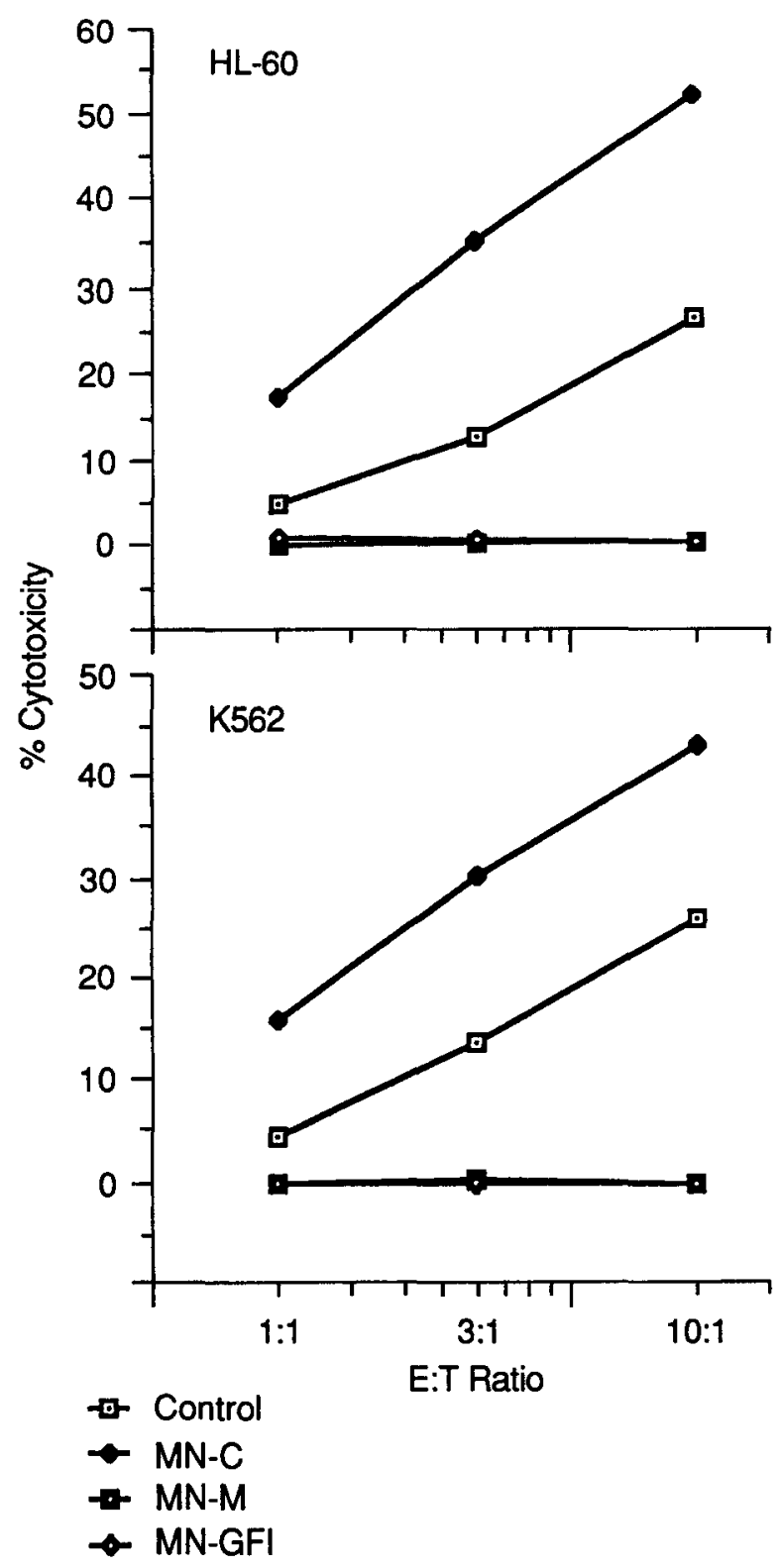

Fig. 3. Percent cytotoxicity of IL-2- (MN-C) and GM-CSF- (MN-M) dependent leukemic cell cultures, the growth factor independent leukemic cell cultures (MN-GFI) against the NK-sensitive target cell line K562 and the NK-resistant target cell line HL-60 in a chromium release assay. Control were peripheral blood mononuclear cells from a healthy donor which were cultured in the presence of IL-2 $100 \mathrm{U} / \mathrm{ml}$ for 14 days. Mean values of triplicates are given, SEM was $<5 \%$. Representative data of one experiment (which were reproduced in two additional experiments) are shown

Such a mechanism has recently been described in B- and pre-B-cell lymphomas which were derived from $\mathrm{E} \mu-m y c$ transgenic murine bone marrow cells. After coinfection with the viral oncogene v-raf these B-lineage tumors displayed "lin- 


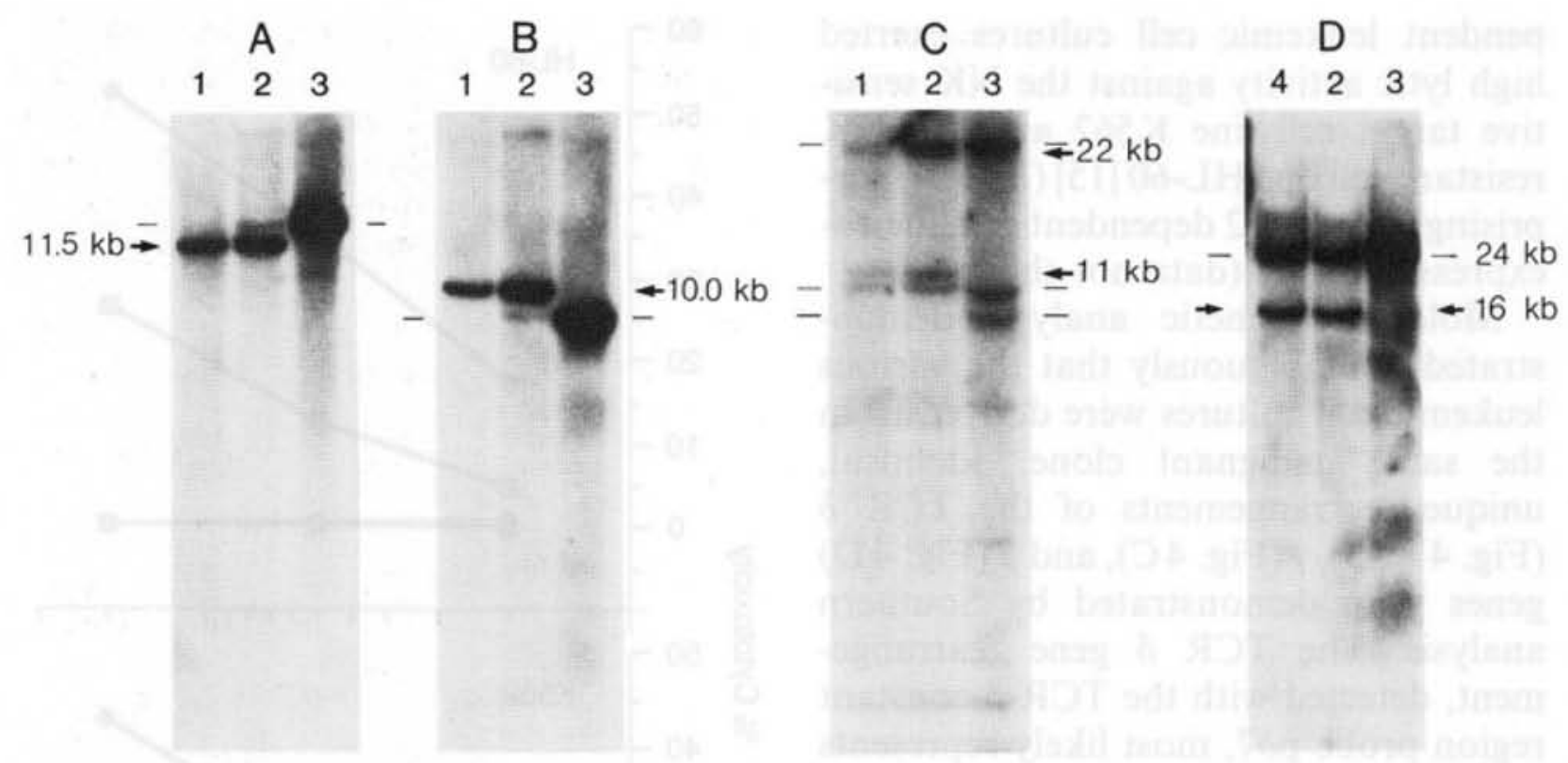

Fig. 4. High molecular weight DNA from IL-3-cultured (lane 1), IL-2-dependent (lane 4), uncultured leukemic cells (làne 2) and germline control (lane 3) were digested with Bam HI (Fig. 4A, D) and Xba I (Fig. 4B,C) and hybridized with the genomic TCR $\delta$ probe $\mathrm{p} \delta 7$ (Fig. $4 \mathrm{~A}, \mathrm{~B}$ ), the TCR $\gamma$ cDNA probe pT $\gamma 1$ (Fig. $4 \mathrm{C}$ ) and the TCR $\beta$ cDNA probe T $\beta$. Germline bands are indicated with bars, rearranged bands with arrows. (Reproduced from the Journal of Experimental Medicine, 1989, vol. 169, pp. 1101-1122, by copyright permission of The Rockefeller University Press)

Table 1. Cytogenetic studies of cultured leukemic cells

\begin{tabular}{|c|c|c|c|}
\hline \multirow[t]{2}{*}{ Cultures } & \multicolumn{2}{|c|}{$\begin{array}{l}\text { No. metaphases } \\
\text { analyzed }\end{array}$} & \multirow[t]{2}{*}{ G-banded karyotypes } \\
\hline & total & per clone & \\
\hline $\begin{array}{l}\text { Growth factor } \\
\text { independent }\end{array}$ & 10 & $\begin{array}{l}7 \\
2 \\
1\end{array}$ & $\begin{array}{l}47, X Y,+19, \operatorname{del}(6)(q 15 q 25), t(1 ; 10 ; 12)(q 25 ; p 13 ; p 13) \\
47, X Y,+19, \operatorname{del}(6)(q 15 q 25), \operatorname{dirdup}(17)(q 11.2 \rightarrow q 23) \\
\mathrm{t}(1 ; 10 ; 12)(\mathrm{q} 25 ; \mathrm{p} 13 ; \mathrm{p} 13) \\
48, X Y,+19, \operatorname{del}(6)(\mathrm{q} 15 \mathrm{q} 25),+\operatorname{del}(6)(\mathrm{q} 15 \mathrm{q} 25) \\
\mathrm{t}(1 ; 10 ; 12)(\mathrm{q} 25 ; \mathrm{p} 13 ; \mathrm{p} 13)\end{array}$ \\
\hline GM-CSF & 10 & $\begin{array}{l}2 \\
8\end{array}$ & $\begin{array}{l}48, X Y,+17,+\operatorname{del}(6)(\mathrm{q} 15 \mathrm{q} 25), \mathrm{t}(1 ; 10 ; 12)(\mathrm{q} 25 ; \mathrm{p} 13 ; \mathrm{p} 13) \\
49, \mathrm{XY},-7,+13,+19,+\operatorname{del}(6)(\mathrm{q} 15 \mathrm{q} 25), \\
\mathrm{t}(1 ; 10 ; 12)(\mathrm{q} 25 ; \mathrm{p} 13 ; \mathrm{p} 13),+\operatorname{der}(7), \mathrm{t}(7 ; 17)(\mathrm{q} 36 ; 21)\end{array}$ \\
\hline IL-3 & 10 & $\begin{array}{l}5 \\
2 \\
3\end{array}$ & $\begin{array}{l}47, \mathrm{XY},+19, \operatorname{del}(6)(\mathrm{q} 15 \mathrm{q} 25), \mathrm{t}(1 ; 10 ; 12)(\mathrm{q} 25 ; \mathrm{p} 13 ; \mathrm{p} 13) \\
48, \mathrm{XY},+19, \operatorname{del}(6)(\mathrm{q} 15 \mathrm{q} 25),+\operatorname{del}(6)(\mathrm{q} 15 \mathrm{q} 25) \\
\mathrm{t}(1 ; 10 ; 12)(\mathrm{q} 25 ; \mathrm{p} 13 ; \mathrm{p} 13) \\
49, \mathrm{XY},+17,+19,+\operatorname{del}(6)(\mathrm{q} 15 \mathrm{q} 25) \\
\mathrm{t}(1 ; 10 ; 12)(\mathrm{q} 25 ; \mathrm{p} 13 ; \mathrm{p} 13)\end{array}$ \\
\hline
\end{tabular}

(Reproduced from the Journal of Experimental Medicine, 1989, vol. 169, pp. 1101-1122, by copyright permission of The Rockefeller University Press).

eage instability" and underwent "lineage switch" to macrophages [22]. Whether similar mechanisms are operational in our novel leukemic cell line is currently under investigation. Further studies will specifically address possible mechanisms involved in the process of multilineage differentiation in this instructive leukemia. We hope that these studies will be useful for a better understanding of 
events of early lymphohematopoiesis, notably of the mechanisms that are involved in the irreversible commitment of multipotent progenitors to different cell lineages.

Acknowledgements. The authors thank Barbara Streifel for her expert technical assistance in performing the cytogenetic studies and Christopher W. Wilkowski for preparing $\mathrm{p} \delta 7$. The authors are indebted to Celia Connoy and Lia Gore for editorial assistance.

\section{References}

1. Broxmeyer HE (1984) Colony assays of hematopoietic progenitor cells and correlations to clinical situations. CRC Crit Rev Oncol Hematol 1:227

2. Clark SC, Kamen R (1987) The human hematopoietic colony-stimulating factors. Science 236: 1229

3. Metcalf D (1984) The hematopoietic colony stimulating factors. Elsevier, Amsterdam

4. Dexter TM, Allen TD, Lajtha LG (1977) Hematopoietic stem cells in vitro. J Cell Physiol 91:335

5. Whitlock CA, Witte ON (1982) Longterm culture of B lymphocytes and their precursors from murine bone marrow. Proc Natl Acad Sci USA 79:3608

6. Foon TA, Todd RF (1986) Review: Immunological classification of leukemia and lymphoma. Blood 68:1

7. Greaves MF, Chan LC, Furley AJW, Watt SM, Molgaard HV (1986) Lineage promiscuity in hematopoietic differentiation and leukemia. Blood 67:1

8. Minden MD, Mak TW (1986) The structure of the $\mathrm{T}$ cell antigen receptor. Blood 68: 327

9. Toyonaga B, Mak TW (1987) Genes of the $\mathrm{T}$-cell antigen receptor in normal and malignant $T$ cells. Annu Rev Immunol 5:585

10. Hershfield MS, Kurtzberg J, Harden E, Moore JO, Whang-Pengh J, Haynes BF (1984) Conversion of a stem cell leukemia from a T-lymphoid to a myeloid phenotype induced by the adenosine deaminase inhibitor 2'-deoxycoformycin. Proc Natl Acad Sci USA 81:253

11. Kurtzberg J, Bigner SH, Hershfield MS (1985) Establishment of the DU.528 human lymphohematopoietic stem cell line. J Exp Med 162:1561
12. Griesinger $F$, Arthur DC, Brunning R, Parkin JL, Ochoa AC, Miller WJ, Wilkowski CW, Greenberg JM, Hurvitz C, Kersey JH (1989) Mature T-lineage leukemia with growth factor induced multilineage differentiation. J Exp Med 169:1101

13. Griesinger F, Greenberg JM, Kersey JH (1989) $\mathrm{T}$ cell receptor gamma and delta rearrangements in hematologic malignancies: Relationship to lymphoid differentiation. J Clin Invest 84:506

14. Dialynas DP, Murre C, Quertermous T, Boss JM, Leuden JM, Seidman JG, Strominger JL (1986) Cloning and sequence analysis of complementary DNA encoding and aberrantly rearranged human T-cell $\gamma$ chain. Proc Natl Acad Sci USA 83:2619

15. Ochoa AC, Gromo G, Alter BJ, Sondel P, Bach FH (1987) Long term growth of lymphokine activated killer (LAK) cells: Role of anti CD3, $\beta$-IL-1, interferon- $\gamma$ and $-\beta$. J Immunol 138: 2728

16. Flynn PJ, Miller WJ, Weisdorf DJ, Arthur DC, Brunning R, Branda RF (1983) Retinoic acid treatment of acute promyelocytic leukemia: in vitro and in vivo observations. Blood 62:1211

17. Look AT, Peiper SC, Ashmun RA (1987) Binding of independently derived monoclonal antibodies to unique human myeloid differentiation antigens. In: McMichael AJ (ed) Leukocyte typing III. White cell differentiation antigens. Oxford University Press, Oxford, p 626

18. Lanier LL, Le AM, Civin CI, Loken MR, Phillips JH (1986) The relationship of CD16 (Leu 11) and Leu 19 (NKH-1) antigen expression on human peripheral blood NK cells and cytotoxic T-lymphocytes. J Immunol 136:4480

19. Lanier LL, Phillips JH (1986) Evidence for three types of human cytotoxic lymphocytes. Immunol Today 7:132

20. Hata S, Clabby M, Devlin P, Spits H, de Vries JE, Krangel MS (1989) Diversity and organization of human $T$ cell receptor $\delta$ variable segments. J Exp Med 169:41

21. Griesinger F, Kersey JH (1988) Lineage restriction and diversity of $\mathrm{T}$-cell receptor delta (TCR $\delta$ ) rearrangements in hematopoietic malignancies. Blood 72 (Suppl 1): $196 \mathrm{a}$

22. Klinken SP, Alexander WS, Adams JM (1988) Hematopoietic lineage switch: vraf oncogene converts $\mathrm{E} \mu$-myc transgenic B cells into macrophages. Cell 53:857 